\title{
RISK-FACTORS FOR NON-ADHERENCE TO ANTIRETROVIRAL THERAPY
}

\author{
Márcia Cristina Fraga SILVA(1), Ricardo Arraes de Alencar XIMENES(1,2), Demócrito Barros MIRANDA FILHO(2), Luciano Wagner de Melo Santiago ARRAES(3), \\ Mecleine MENDES(4), Ana Caroline de Sobral MELO(4) \& Paola Rebeka de Melo FERNANDES(4)
}

\begin{abstract}
SUMMARY
Cross-sectional study analyzed as case-control to identify risk factors for non-adherence to antiretroviral therapy. We studied 412 out-clinics HIV infected subjects of three public hospitals of Recife, Pernambuco. The objective was to examine the association between non-adherence to the antiretroviral therapy and biological, social-behavior and demographics and economic factors, factors related to the disease and/or treatment, factors related to life habits and depression symptoms. Variables significantly associated with non-adherence to antiretroviral therapy were: time elapsed since HIV diagnosis $(p=0.002)$, daily dose $(p=0.046)$, use of alcohol $(\mathrm{p}=0.030)$ and past drug use $(\mathrm{p}=0.048)$, and borderline $p$-values were found for educational level $(\mathrm{p}=0.093)$ and family monthly income $(\mathrm{p}=0.08)$. In the multivariable analysis, the factors that remained in the final model were family monthly income, time period with HIV infection and use of alcohol. No association was observed between non-adherence to antiretroviral therapy and gender, age, sexual orientation, marital status, educational level and place of residence.

Based on our results and the local situation we suggest: assessment of social needs; training of partners and/or families on supporting adherence, creation of "adherence groups" to motivate and to reassure patients on the benefits of treatment; counseling and/or psychotherapy for alcohol drinkers.
\end{abstract}

KEYWORDS: Antiretroviral therapy; Risk-factors.

\section{INTRODUCTION}

The use of combined antiretroviral agents starting in 1996, along with the routine use of primary prophylaxis for opportunistic infections, has had an important effect on the natural evolution of HIV disease, resulting in a reduction in complications from immune deficiency and an important reduction in morbidity and mortality ${ }^{27}$. This has given the disease the character of a chronic and potentially controllable illness. However, to achieve optimal viral suppression it is necessary a high level of adherence for an indefinite time period ${ }^{29}$. Consequently non-adherence to the proposed antiretroviral regimen is considered one of the greatest dangers to the response to treatment on an individual level and the dissemination of resistant viruses on the community level ${ }^{14}$.

Recent papers have described different methods for measuring adherence and discussed the advantages and disadvantages of each one but there is still no consensus concerning a gold standard ${ }^{26,30}$. Self-report measures of antiretroviral adherence can be robust, as they have been found to be associated with other indirect measures of adherence and viral load ${ }^{30}$.

Adherence is the main factor health services act in order to enhance the effectiveness of the treatment as well as decrease the chance of the emergence of HIV resistance to antiretroviral drugs. For this reason, institutional and non-institutional guidelines have been produced ${ }^{22,26,34}$.

Non-adherence is multifactorial and several groups of variables have been implicated in its occurrence ranging from individual to health service and social factors $2,4,15,24$.

The aim of the present study was to identify the main predictive factors regarding non-adherence to antiretroviral treatment among patients with HIV infection, with an emphasis on biological, social, behavioral, demographic, economic and psychological aspects. The understanding of such factors and their determinants is one of the main steps toward seeking new intervention strategies and thereby assuring therapeutic effectiveness.

\section{METHODOLOGY}

The study involved male and female adult patients infected with HIV and in antiretroviral therapy for more than 15 days. All patients were in treatment from March to August 2001 and attending the out-patient clinics of one of the three reference hospitals for HIV/AIDS in the city of Recife: the Oswaldo Cruz University Hospital, the Correia Picanço Hospital and the Clinical Hospital in Recife, PE, Brazil.

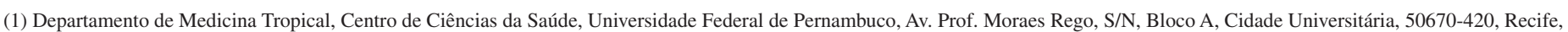
Pernambuco, Brasil.

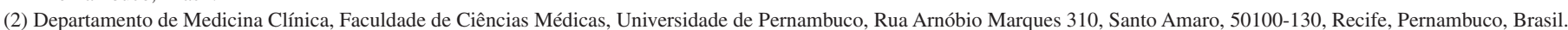

(3) Faculdade de Ciências Médicas, Universidade de Pernambuco, Rua Arnóbio Marques, 310, Santo Amaro, 50100-130, Recife, Pernambuco, Brasil.

(4) Centro de Ciências da Saúde, Universidade Federal de Pernambuco, Av. Prof. Moraes Rego, S/N, Bloco A, Cidade Universitária, 50670-420, Recife, Pernambuco, Brasil.

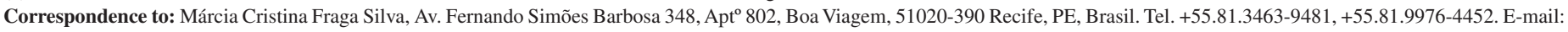
marcia.fraga@ig.com.br 


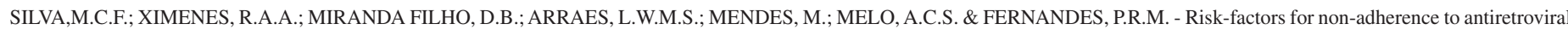
therapy. Rev. Inst. Med. trop. S. Paulo, 51(3): 135-139, 2009.

A cross-sectional study was carried out and a case-control strategy was used in the analysis. HIV patients that reported having ingested less than $90 \%$ of the total number of the prescribed antiretroviral medication in the previous five days were considered as "cases" and those that reported having ingested $90 \%$ or more of the total number of the prescribed antiretroviral medication in the previous five days were considered as "controls". The following variables were selected for the study: biological (gender, age); socio-behavioral and demographic (sexual behavior, marital status, level of education, city of residence); economic (work situation, monthly personal income and monthly family income); factors related to the disease and treatment (hospital attended, time elapsed since diagnosis, time elapsed since start of treatment, presence of symptoms, antiretroviral regimen in use, number of daily pills, expectation regarding treatment); factors related to living habits (use of alcohol, present or past drug use - marihuana, LSD, cocaine, heroin, ecstasy, crack and benzene derivates (participation in non-governmental organizations); and factors related to depression symptoms.

Data were collected using a questionnaire specially elaborated for the study through the Hamilton Scale ${ }^{13}$ for depression assessment, with a cutoff point of 18 for the diagnosis of moderate to severe depression. Data were also obtained from the medical charts of patients who were unable to supply information as to the antiretroviral regimen being used.

To calculate the sample size, the frequency of exposure was based on two variables studied by GORDILLO et al ${ }^{10}$. The sample size estimated was 352 patients for the mode of HIV transmission variable and 372 for the current work situation variable.

For the purpose of the analysis the variables were grouped in sets: biological, economic, factors related to disease and treatment, factors related to living habits and factors related to depression symptoms. The association of each variable with non-adherence was tested using the chi-square test, the odds ratio, the $95 \%$ confidence interval and $p$ value; a $p$-value $<0.05$ being considered statistically significant. Multivariate analysis was used to control the effect of each variable for the others. The model was first saturated with all variables whose association with death showed a $p$-value $<0.10$ in the univariable analysis. Then the statistical significance of the removal of each variable from the model was tested, a $p$-value $<0.10$ being the cut-off point considered.

From the identification of the variables whose association with non-adherence showed a $p$-value $<0.10$ in the univariable analysis, a multivariable analysis was carried out in each set using multiple logistic regression. Finally, the variables which were retained in the final model in each set were adjusted for the effect of the others.

The EPI-INFO (version 6.0) ${ }^{5}$ software program was used for calculating the sample size, as well as for the elaboration of the databank and the data analysis. For the logistic regression the SPSS-PC ${ }^{31}$ was used.

\section{RESULTS}

A total of 412 patients were studied, with a proportion of one case for every three controls; the frequency of non-adherence found was $25.73 \%$. The mean age of the patients was 36 years, ranging from 17 to 67 years, and $69.2 \%$ of them were males. Concerning the level of education, approximately $51 \%$ of the patients had less than nine years of schooling, $7.3 \%$ of them being illiterate. Only $12 \%$ had university education. Around $62 \%$ of the patients had a family income $\leq 3$ minimum wages and most of them lived in the Metropolitan Region of Recife. The majority $(67 \%)$ had started treatment with HAART in the previous three years and $66 \%$ were symptomatic when the treatment was prescribed. Alcohol consumption was referred by $30 \%$ of the patients, past use of illicit drugs by $16.5 \%$ and present use by $6 \%$.

The following variables showed a statistically significant association with non-adherence in the univariable analysis: time elapsed since the diagnosis of HIV infection $(p=0.002)$; larger number of daily pills ( $p$ $=0.046)$; use of alcohol $(p=0.03)$; and past drug use $(p=0.048)$. The variable "daily number of pills" had a statistically significant $p$-value (for all risk categories), but only those patients who used to take more than 15 pills per day had a statistically significant $95 \%$ confidence interval for the odds ratio. A borderline association was observed with the following variables: level of education $(p=0.093)$ and monthly family income $(p=0.08)$. All variables for which the $p$-value of the association with non-adherence was equal to or less than 0.10 were introduced in a multivariate model in each set (socioeconomic, factors related to disease and treatment, factors related to living habits), - Tables 1, 2, 3 - and, subsequently, a final multivariate analysis was carried out with those selected in each group (Table 4). Monthly family income, time elapsed since diagnosis and use of alcohol remained in the final model, showing an independent association with non-adherence.

Table 1

Odds ratio, confidence intervals and $p$-values for the association between socioeconomic factors and adherence to antiretroviral treatment, in patients attending the out-clinics of the reference hospitals for HIV treatment in Recife, from March to August 2001

\begin{tabular}{|c|c|c|c|}
\hline & \multicolumn{2}{|c|}{$\begin{array}{l}\text { Adherence in the previous } \\
\text { five days }\end{array}$} & \multirow[b]{2}{*}{$p$-value } \\
\hline & Odds Ratio & $95 \% \mathrm{IC}$ & \\
\hline Level of Education & & & $p=0.093$ \\
\hline 11 years of schooling & 1 & - & \\
\hline Eight years of schooling & 0.86 & $0.37-2.03$ & \\
\hline Four years of schooling & 1.35 & $0.61-3.04$ & \\
\hline Illiterate & 2.24 & $0.74-6.82$ & \\
\hline $\begin{array}{l}\text { Family Income } \\
\text { (minimum wage) }\end{array}$ & & & $p=0.080$ \\
\hline$>7$ & 1 & - & \\
\hline $4-6$ & 1.08 & $0.43-2.69$ & \\
\hline $1-3$ & 2.01 & $0.99-4.17$ & \\
\hline$<1$ & 1.95 & $0.65-5.80$ & \\
\hline
\end{tabular}

\section{DISCUSSION}

Adherence to any type of health care is strongly recognized as a complex, multifaceted scientific issue. The lack of methodological standards makes assessments and comparisons between levels of 
Table 2

Odds ratio, confidence intervals and $p$-values for the association between treatment related factors and adherence to antiretroviral treatment, in-patients attending the out-clinics of the reference hospitals for HIV treatment in Recife, from March to August 2001

\begin{tabular}{lccc}
\hline & \multicolumn{2}{c}{$\begin{array}{c}\text { Adherence in the } \\
\text { previous five days }\end{array}$} \\
\cline { 2 - 3 } & Odds Ratio & $95 \%$ IC & $p$-value \\
\hline $\begin{array}{l}\text { Time elapsed since HIV } \\
\text { diagnosis (years) }\end{array}$ & & $p=0.002$ \\
$<1$ & 1 & - & \\
$1-3$ & 4.03 & $1.82-9.14$ & \\
$4-5$ & 2.43 & $0.99-6.06$ & \\
$6-10$ & 2.72 & $1.14-6.59$ & \\
$>10$ & 1.14 & $0.11-6.32$ & \\
Daily number of pills & & & \\
$1-4$ & 1 & & \\
$5-10$ & 1.04 & $0.50-2.17$ & \\
$11-15$ & 1.11 & $0.49-2.54$ & \\
$>15$ & 2.54 & $1.03-6.35$ & \\
\hline
\end{tabular}

Table 3

Odds ratio, confidence intervals and $p$-values for the association between habits and adherence to antiretroviral treatment, in patients attending the out-clinics of the reference hospitals for HIV treatment in Recife, from March to August 2001.

\begin{tabular}{lccc}
\hline & \multicolumn{2}{c}{ Adherence in the previous 5 days } & \\
\cline { 2 - 3 } & Odds Ratio & $95 \%$ IC & $p$-value \\
\hline Use of alcohol & & & $p=0.030$ \\
No & 1 & - & \\
Yes & 1.67 & $1.02-2.70$ & \\
Past use of drugs & & & $p=0.048$ \\
No & 1 & - & \\
Yes & 1.75 & $1.00-3.03$ & \\
\hline
\end{tabular}

adherence extremely difficult. As such, it is always necessary to consider the method used and the level at which adherence was defined. Several direct and indirect methods have been employed, but none can be considered the "gold standard" . Despite being classically considered as methods that tend to overestimate adherence measures, when conducted well, those utilizing the direct questioning of the patients are adequate indicators of actual adherence.

Another problem regards the level of adherence necessary for obtaining therapeutic effectiveness. Most studies on antiretroviral agents use a cut-off point of $80 \%$, which is based on data from other chronic diseases, such as diabetes and hypertension ${ }^{6,18}$. With the HIV, which has an extremely high power of replication and mutation, there is no reassurance that this
Table 4

Adjusted odds ratio, confidence intervals and $p$-values for the association between socioeconomic and treatment related factors and habits with adherence to antiretroviral treatment, in patients attending the out-clinics of the reference hospitals for HIV treatment in Recife, from March to August 2001

\begin{tabular}{lccc}
\hline & \multicolumn{3}{c}{ Adherence in the previous 5 days } \\
\cline { 2 - 4 } & Odds Ratio & $95 \%$ IC & $p$-value \\
\hline $\begin{array}{l}\text { Family income } \\
\text { (minimum wage) } *\end{array}$ & & $p=0.024$ \\
$<1$ & 1 & - & \\
$1-3$ & 2.51 & $7.05-0.89$ \\
$4-6$ & 2.33 & $4.66-1.17$ \\
$>7$ & 1.15 & $0.48-2.74$
\end{tabular}

Time elapsed since $p=0.045$ diagnosis (years)

$\begin{array}{lcc}<1 & 1 & - \\ 1-3 & 3.90 & 8.70-1.74 \\ 4-5 & 2.63 & 6.51-1.06 \\ 6-10 & 3.23 & 7.70-1.35 \\ >10 & 1.10 & 5.85-0.20\end{array}$

Use of alcohol

$p=0.095$

No

Yes

1.56

$0.93-2.53$

* The family income was relative to the minimum wage (one minimum wage was approximately US\$100.00).

cut-off point is associated with parameters of clinical and/or laboratorial improvement - as studies on HIV have suggested, less than excellent adherence may result in the emergence of resistant viruse ${ }^{3,21}$. The results of two randomized multicenter clinical trials conducted in the USA showed that adherence predicted nondetectable HIV RNA levels at 12 months of follow-up ${ }^{20}$. However newer data with NNRTI-based regimens (which also likely apply to ritonavir-boosted, PI-based regimens) suggest that current antiretroviral regimens can tolerate some degree of imperfect adherence while maintaining the beneficial effects of HIV therapy in most patients ${ }^{11}$. Thus the identification and development of antiretroviral combinations that show a high pharmacokinetic or genetic barrier to resistance are important in the long-term management of $\mathrm{HIV}^{19}$.

Furthermore, other aspects are keys to the effectiveness of many components of antiretroviral treatment, such as the capacity of the patient in adhering to special instructions regarding dose intervals and dietary guidelines ${ }^{33}$.

In the present study, adequate adherence was considered to be the use of at least $90 \%$ of the prescribed medications ${ }^{10,17}$, taking into account the previous five days as a proxy of habitual behavior. The frequency of non-adherence was $25.73 \%$, similar to the figure found in a study conducted in 60 outpatients services located in seven states of Brazil ${ }^{25}$. Other Brazilian studies reported figures from 17 to $48 \%$ of non-adherence and they explained that variation by the different ways adherence was 


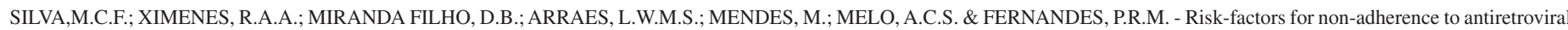
therapy. Rev. Inst. Med. trop. S. Paulo, 51(3): 135-139, 2009.

conceptualized and measured and by a lack of definition of what should be considered optimal adherence ${ }^{12}$. BONOLO et al. ${ }^{2}$ review 43 articles on adherence to HAART. They found a mean rate of non-adherence of $30.4 \%$, range from $5 \%$ to $67 \%$. Interestingly, the rates reported in developing and developed countries were similar ${ }^{1}$.

Selection bias may have occurred, as only those patients who continued treatment were included in the study, whereas those who had abandoned treatment and no longer showed up to the medical consultations were left out. It is also possible that the patients who agreed to take part in the study were those who had better adherence. Moreover, as this study was based on facts that had already occurred and the information was obtained directly from the patients, there may have been failure in the use of medication which was not reported either because of memory lapse or for some other reason, leading to the misclassification of exposure. Non-differential misclassification, as it is likely to have occurred, may underestimate the measures of association. In an attempt to minimize some of these problems, data were collected from patients being treated at three reference hospitals in Recife, there was a great effort to avoid non-response and standard procedures and questionnaires were used. The number of patients studied per hospital was proportional to the number of patients registered and receiving antiretroviral therapy in each of these services. Cross-sectional studies are usually classified as descriptive but, in this case, the presence of appropriate comparison groups allows testing statistical association. However association refers to statistical dependence between two variables but it does not imply that the observed relationship is one of cause and effect.

The association between socioeconomic condition and non-adherence is controversial, although divergences can be partly explained by the differences among the groups studied ${ }^{16,21,33}$. There is, however, an increasing inclination to consider socioeconomic condition (as assessed through income, level of education, job and housing conditions) as having a poor predictive power, except in cases of extreme poverty ${ }^{9,14}$. For instance, the study conducted in several Brazilian states found an association between a very low educational level and non-adherence ${ }^{25}$. It is possible that such socioeconomic factors are a proxy of other factors that could be the actual determinants of non-adherence, such as difficulty in obtaining adequate information on health and disease, difficult access to treatment centers, treatment costs and a lack of credibility in health centers ${ }^{32}$. It should be pointed out that most international studies are carried out in rich countries that have far more adequate systems of social support.

In relation to the time elapsed since start of the antiretroviral treatment, it was not associated to non-adherence in this study. This differs from the literature, which states that in chronic diseases adherence usually declines over time ${ }^{8}$. However, it is necessary to keep in mind that most studies concerning length of treatment cover longer time periods, such as in the case of arterial hypertension, while the dissemination of antiretroviral therapy is relatively recent. The hypothesis that the average length of treatment was not long enough to demonstrate an effect on nonadherence may be reinforced by the finding that a longer time elapsed since diagnosis of HIV implied a greater risk of non-adherence, even after adjustment for other variables. The increase in survival that has been observed in recent years may have produced a sense of "invulnerability" among the group of patients with a longer time since diagnosis, which may have contributed to low adherence.
Despite the fact that the relation between alcohol and lower adherence is classic in the literature on tuberculosis ${ }^{8}$, its association with antiretroviral therapy has not been sufficiently studied. The relation between drug use and antiretroviral therapy is controversial. In the present study, in the analysis of the association between non-adherence and the use of drugs or alcohol, it was observed that both variables were associated with non-adherence in the univariate analysis, but the variable drug use lost the statistical significance in the multivariate model. It should be pointed out, however, that the frequency of patients that reported excessive use of alcohol or intravenous drugs was very low. Marijuana appeared as the principal illicit substance used. Studies on drug use and HIV focus mainly on intravenous drug users and it seems well established that such individuals exhibit higher rates of refusal to treatment ${ }^{28}$.

The Brazilian Ministry of Health proposed several strategies to be implemented in Health Units to increase adherence to antiretroviral treatment ${ }^{22}$. Integrated measures have been suggested: reduction of vulnerability and stigma, strengthen the participation of the users of health services increasing the dialogue with health professionals and a joint responsibility on the treatment ${ }^{23}$. In addition to global strategies, different sets of targeted interventions may be needed for special groups due to the wide spectrum of factors that may be related to non-adherence ${ }^{29}$.

This study, by identifying risk factors for non-adherence in this setting, allows the early recognition of higher risk subgroups that should be carefully monitored along the antiretroviral treatment to increase its effectiveness. These subgroups could be identified with a screening for low monthly income, longer period elapsed since HIV diagnosis and alcohol drinkers. We suggest the following strategies, based on our results and the local situation: assessment of social needs; training of partners and/or families on supporting adherence, creation of "adherence groups" to motivate and to reassure patients on the benefits of treatment; counseling and/or psychotherapy for alcohol drinkers.

\section{RESUMO}

\section{Fatores preditivos de não-adesão à terapia antiretroviral}

Estudo transversal com análise tipo caso-controle, que avaliou 412 pacientes de hospitais públicos do Recife - PE, com o objetivo de identificar fatores preditivos de não adesão à terapia antiretroviral. Verificou-se associação entre não adesão à terapia antiretroviral e aspectos biológicos, sócio-comportamentais e demográficos, econômicos, relacionados à doença e ao tratamento, aos hábitos de vida e aos distúrbios do humor.

Variáveis com associação estatisticamente significante com não adesão na análise univariada foram: tempo de diagnóstico $(p=0,002)$, maior número diário de comprimidos $(p=0,046)$, uso de álcool $(p=$ $0,030)$ e uso de drogas no passado $(p=0,048)$. Observou-se associação limítrofe com grau de instrução $(p=0,093)$ e renda mensal familiar ( $p$ $=0,08)$. Após análise multivariada, permaneceram no modelo final: renda mensal familiar, tempo de diagnóstico e uso de álcool. Não houve associação entre gênero, idade, comportamento sexual, estado civil, grau de instrução, município de residência e não adesão à terapia antiretroviral.

Baseados nos nossos resultados e nas características da população estudada sugerimos: valorização das necessidades sociais, sensibilização de parceiros e/ou familiares para estimular a adesão, criação de grupos 
de adesão para motivar e persuadir os pacientes sobre os benefícios do tratamento, aconselhamento e/ou psicoterapia para alcoolistas.

\section{REFERENCES}

1. BONOLO, P.F.; GOMES, R.R.F.M. \& GUIMARÃES, M.D.C. - Adesão à terapia antiretroviral (HIV/aids): fatores associados e medidas de adesão. Epidem. Serv. Saúde, 16: $261-278,2007$

2. BONOLO, P.F.; CÉSAR, C.C.; ACURCIO, F.A et al. - Non-adherence among patients initiating antiretroviral therapy: a challenge for health professionals in Brazil. AIDS, 19(suppl. 4): s5-s13, 2005.

3. CARPENTER, C.C.J.; FISCHL, M.A.; HAMMER, S.M. et al. - Antiretroviral therapy for HIV infection in 1997: updated recommendations of the International AIDS Society-USA Panel. J. Amer. med. Ass., 277: 1962-1969, 1997.

4. CARRIERI, M.P.; LEPORT, C.; PROTOPOPESCU, C. et al. - Factors associated with nonadherence to highly active antiretroviral therapy: a 5-year follow-up analysis with correction for the bias induced by missing data in the treatment maintenance phase. J. acquir. immune Defic. Syndr., 41: 477-485, 2006.

5. CDC. Centers for Disease Control and Prevention - Epi Info. Version 6.04. Atlanta, 2007. Available from: http://www.lampada.uerj.br/epiinfo/download.htm.

6. ELDRED, L.J.; WU, A.W.; CHAISSON, R.E. \& MOORE, R.D. - Adherence to antiretroviral and Pneumocystis prophylaxis in HIV disease. J. acquir. immune Defic. Syndr., 18: 117-125, 1998.

7. FARMER, K. C. - Methods for measuring medication regimen adherence in clinical trials and practice. Clin. Therap., 21: 1074-1090, 1999.

8. FRANK, I. - Once-daily HAART: toward a new treatment paradigm. J. acquir. immune Defic. Syndr., 31(suppl. 1): S10-S15, 2002.

9. GONÇALVES, H.; COSTA, J.S.D.; MENEZES, A.M.B.; KNAUTH, D. \& LEAL, O.F. - Adesão à terapêutica da tuberculose em Pelotas, Rio Grande do Sul: na perspectiva do paciente. Cadern. Saúde públ. (Rio de J.), 15: 777-787, 1999.

10. GORDILLO, V.; DEL AMO, J.; SORIANO, V. \& GONZÁLEZ-LAHOZ, J. Sociodemographic and psychological variables influencing adherence to antiretroviral therapy. AIDS, 13: 1763-1769, 1999.

11. GULICK, R.M. - Adherence to antiretroviral therapy: how much is enough? Clin. infect. Dis., 43: 942-944, 2006.

12. HACKER, M.A.; KAIDA, A.; HOGG, R.S. \& BASTOS, F.I. - The first ten years: achievements and challenges of the Brazilian program of universal access to HIV/ AIDS comprehensive management and care, 1996-2006. Cadern. Saúde públ. (Rio de J.), 23(suppl. 3): S345-S359, 2007.

13. HAMILTON, M. - A rating scale for depression. J. Neurol. Neurosurg. Psychiat., 23: $56-62,1960$

14. HECHT, F.M.; GRANT, R.M.; PETROPOULOS, C.J. et al. - Sexual transmission of an HIV-1 variant resistant to multiple reverse-transcriptase and protease inhibitors. New Engl. J. Med., 339: 307-311, 1998.

15. HOLSTAD, M.K.M.; PACE, J.C.; DE, A.K. \& URA, D.R. - Factors associated with adherence to antiretroviral therapy. J. Ass. Nurses AIDS Care, 17: 4-15, 2006.

16. KLEEBERGER, C.A.; PHAIR, J.P.; STRATHDEE, S.A. et al. - Determinants of heterogeneous adherence to HIV-antiretroviral therapies in the multicenter AIDS cohort study. J. acquir. immune Defic. Syndr., 26: 82-92, 2001.

17. KNOBEL, H.; CARMONA, A.; GRAU, S.; PEDRO-BOTET, J. \& DÍEZ, A. - Adherence and effectiveness of highly active antiretroviral therapy. Arch. intern. Med., 158: 1953, 1998.
18. LÓPEZ-SUÁREZ, A.; FERNÁNDEZ-GUTIÉRREZ, Del A.; PÉREZ-GUZMÁN, E. \& GIRÓN-GONZÁLEZ, J.A. - Adherence to the antiretroviral treatment in asymptomatic HIV-infected patients. AIDS, 12: 685-686, 1998.

19. LUCAS, G.M. - Antiretroviral adherence, drug resistance, viral fitness and HIV disease progression: a tangled web is woven. J. Antimicrob. Chemother., 55: 413-416, 2005

20. MANNHEIMER, S.; FRIEDLAND, G.; MATTS, J.; CHILD, C. \& CHESNEY, M. - The consistency of adherence to antiretroviral therapy predicts biologic outcomes for human immunodeficiency virus-infected persons in clinical trials. Clin. infect. Dis., 34: $1115-1121,2002$

21. MEHTA, S.; MOORE, R.D. \& GRAHAM, M.H. - Potential factors affecting adherence with HIV therapy. AIDS, 11: 1665-1670, 1997.

22. MINISTÉRIO DA SAÚDE. BRASIL - Adesão aos anti-retrovirais: manual para profissionais de saúde. Brasília, Ministério da Saúde, 2005. Available from: http://www.aids.gov.br/data/documents/storedDocuments/\%7BB8EF5DAF23AE-4891-AD36-1903553A3174\%7D/\%7B51826D39-615A-4F8B-8768EDA75AC80AC6\%7D/Manual\%20de\%20Ades\%E3o\%20Prof $\% 20 \mathrm{Sa} \%$ FAde $\% 20$ ago\%202005.pdf. (accessed in 24 September 2007).

23. MINISTÉRIO DA SAÚDE. BRASIL - Diretrizes para o fortalecimento das ações de adesão ao tratamento para as pessoas que vivem com HIV e AIDS. Brasília, Ministério da Saúde, 2007. Available from: http://bvsms.saude.gov.br/bvs/ publicacoes/diretrizes_tratamento_aids.pdf (accessed in 10 October 2008).

24. MOLAREJO, L.; INÉS, S.; MARCOS, M.; FUERTES, A. \& LUNA, G. - Factors influencing adherence to highly active antiretroviral therapy in Spain. Curr. HIV Res., 4: 221-227, 2006.

25. NEMES, M.I.B.; CARVALHO, H.B. \& SOUZA, M.F.M. - Antiretroviral therapy adherence in Brazil. AIDS, 18(suppl. 3): s15-s20, 2004.

26. OSTERBERG, L. \& BLASCHKE, T. - Drug therapy: adherence to medication. New Engl. J. Med., 353: 487-497, 2005.

27. PALELLA Jr., F.J.; DELANEY, K.M.; MOORMAN, A.C. et al. - Declining morbidity and mortality among patients with advanced human immunodeficiency virus infection. HIV Outpatient Study Investigators. New Engl. J. Med., 338: 853-860, 1998.

28. SHERER, R. - Adherence and antiretroviral therapy in injection drug users. J. Amer. med. Ass., 280: 567-568, 1998.

29. SIMONI, J.M.; FRICK, P.A.; PANTALONE, D.W. \& TURNER, B.J. - Antiretroviral adherence interventions: a review of current literature and ongoing studies. Top. HIV Med., 11: 185-198, 2003.

30. SIMONI, J.M.; KURTH, A.E.; PERSON, C.R. et al. - Self-report measures of antiretroviral therapy adherence: a review with recommendations for HIV research and clinical management. AIDS Behav., 10: 227-245, 2006.

31. SPSS STATISTICAL PACKAGE FOR SOCIAL SCIENCES - SPSS base. Version 11.0. Chicago, 2007. Available from: http://www.spss.com/spss/data_mgmt.htm.

32. SUMARTOJO, E. - When tuberculosis treatment fails. A social behavioral account of patient adherence. Amer. Rev. resp. Dis., 147: 1311-1320, 1993

33. WILliAMS, A.B. - Adherence to highly active antiretroviral therapy. Nurs. Clin. N. Amer., 334: 113-129, 1999.

34. WORLD HEALTH ORGANIZATION - Adherence to long-term therapies: evidence for action. (2003). Available from: http://www.who.int/bookorders/anglais/detart1.

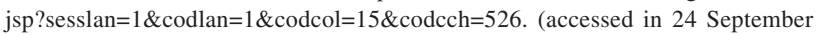
2007).

Received: 26 September 2005

Accepted: 14 April 2009 